REVISTA de

PEDAGOGIE

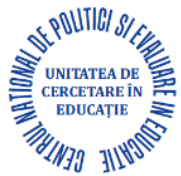

JOURNAL of PEDAGOGY

http://revped.ise.ro

Print ISSN 0034-8678; Online ISSN: 2559 - 639X

\title{
“DISTANCED” TIMES: INVESTIGATING PRE-SERVICE MUSIC TEACHERS' EXPERIENCES ON ONLINE TEACHING AND LEARNING DURING THE COVID-19 PANDEMIC
}

La vremea distanţării: investigarea experienţelor de învăţare şi predare online ale studenţilor viitori profesori de muzică în timpul pandemiei Covid-19

\section{Miruna Luana MIULESCU, Florentina - Lavinia MATEI}

\author{
Journal of Pedagogy, 2021 (1), 111 - 124 \\ https://doi.org/10.26755/RevPed/2021.1/111
}

The online version of this article can be found at: http://revped.ise.ro/en/2021/

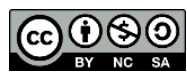

This work is licensed under the Creative Commons Attribution-NonCommercial-ShareAlike 4.0 International License. To view a copy of this license, visit http://creativecommons.org/licenses/by-nc-sa/4.0/ or send a letter to Creative Commons, PO Box 1866, Mountain View, CA 94042, USA.

Published by:

Centrul Național de Politici și Evaluare în Educație UNITATEA DE CERCETARE ÎN EDUCAȚIE

http://www.ise.ro/

https://rocnee.eu/

Further information about Revista de Pedagogie - Journal of Pedagogy can be found at: Editorial Policy: http://revped.ise.ro/editorial-policy/ Author Guidelines: http://revped.ise.ro/en/author-guidelines/ 


\title{
"DISTANCED" TIMES: INVESTIGATING PRE-SERVICE MUSIC TEACHERS' EXPERIENCES ON ONLINE TEACHING AND LEARNING DURING THE COVID-19 PANDEMIC
}

\section{Miruna Luana Miulescu*}

\author{
National Center for Policy and Evaluation in Education, \\ Education Research Unit, \\ Bucharest, Romania \\ miruna.miulescu@gmail.com
}

\section{Florentina - Lavinia Matei**}

University of Bucharest, Faculty of Psychology and Educational Sciences,

Bucharest, Romania mateilavinia92@yahoo.com

\begin{abstract}
The technology use is flourishing in a growing set of educational contexts. Music education is no exception, seeing more and more learning practices be actively incorporated into educational frameworks. Our study seeks to investigate the online teaching and learning experiences of music university students who are participating in the pre-service teacher education during the Covid-19 pandemic. The participants of the present study are pre-service music students $(\mathrm{n}=22)$ enrolled in the teaching education programme in their 2nd or 3rd year at the university. By making use of a phenomenological qualitative inquiry, data was collected through participating at semi-structured interviews via ZOOM videotelephony software in January and February 2021. The key findings indicate a neither overtly positive or negative
\end{abstract}

* Researcher, PhD, Education Research Unit, National Center for Policy and Evaluation in Education (CNPEE), Bucharest, Romania.

** PhD, Faculty of Psychology and Educational Sciences, University of Bucharest, Bucharest, Romania. 
teaching and learning experience, even if the students had to navigate an avalanche of offline learning technology requirements both as students and teachers in a limited amount of time. The results of the study indicate that teacher training programmes should consider the move to virtual teaching and learning as an opportunity for change and to go beyond the emergency online practices and develop quality online educational activities.

Keywords: Covid-19, music education, pre-service teacher, teacher education, technology.

\section{Rezumat}

Utilizarea tehnologiei este înfloritoare într-un set tot mai mare de contexte educa ionale. Educa ia în domeniul muzical nu face excep ie, având în vedere că tot mai multe practici de învă are sunt încorporate în mod activ în cadrul educa ional. Studiul nostru urmăreşte să investigheze experien ele de predare şi învă are online ale studen ilor din domeniul muzical care participă la modulul psihopedagogic în timpul pandemiei Covid-19. Participan ii la studiul de fa ă sunt studen $i$ din domeniul muzical $(n=22)$ inscrişi la modulul psihopedagogic în anul 2 sau 3 la universitate. In cadrul unei investiga ii calitative de tip fenomenologic, datele au fost colectate prin participarea la interviuri semistructurate prin intermediul programului software de videotelefonie ZOOM în lunile ianuarie şi februarie 2021. Principalele constatări indică o experien ă de predare şi învă are nici evident pozitivă, nici negativă, chiar dacă studen ii au fost nevoi i să navigheze într-o avalanşă de cerin e legate de tehnologie în contextul învă ării offline atât ca studen $i$, cât şi ca profesori într-un timp limitat. Rezultatele studiului indică faptul că programele de pregătire a cadrelor didactice ar trebui să ia în considerare trecerea la predarea şi învă area virtuală ca o oportunitate de schimbare şi să depăşească practicile online de urgen ă şi să dezvolte activită $i$ educa ionale online de calitate.

Cuvinte-cheie: cadru didactic în formare, Covid-19, educa ie în domeniul muzical, formarea profesorilor, tehnologie. 


\section{Introduction}

The world has seen an exponential change. The pandemic has disturbed and has had damaging effects on both our personal and professional lives (Pozo et al., 2021; Thomas et al., 2021). As studies have shown (Brown, 2020; Donitsa-Schmidt \& Ramot, 2020; United Nations Educational Scientific and Cultural Organization, 2020), the closure of educational institutions as a consequence of COVID-19 led to substantial changes in education with profound consequences. In order to avoid a ,generational catastrophe”, as pointed out by a UNESCO high-level ministerial meeting in March 2021, it is crucial for countries from all over the world to prioritize education recovery (UNESCO, 2021).

With the advent of COVID-19 in Romania, one of the first responses of education authorities was the closure of educational institutions as a protective measure (CEDEFOP, 2020). This led for teachers and students to a complex process of adaptation to the online schooling, a situation for which neither group was properly equipped.

Several challenges emerged as a consequence of the transition to the digital teaching and learning environment. As research shows (Botnariuc et al., 2020; Dalu et al., 2021), due to the fact that physical presence in classrooms was no longer possible, neither teachers nor students were capable to engage in the usual teaching and learning transactions. Moreover, instructional resources for online delivery of lessons were not promptly accessible in formats that are suitable to the Romanian language and syllabus. A serious problem for educators was the lack of curriculum configuration to the online or blended approach, which led to more confusion. Another challenging topic concerned the absence of or unstable Internet connectivity in some rural communities, and the lack of proper devices that would facilitate online teaching and learning. As educational leadership is concerned, principals had their own hurdles to overcome: they had to create suitable mechanisms for monitoring and assisting educators and students in the digital environment; furthermore, a strong guidance towards systemic change was needed in order to move towards the educational process via the technological medium (Dalu et al., 2021). 


\section{Purpose of the study}

Educators and students are required to extract, evaluate, adopt, rethink, apply and convey knowledge constantly, with the help of a myriad of intertwined channels, modalities and media. A range of technologies can enable us to do so. Music related technology can be distinguished as being deeply connected to acoustics, electronic music, sound engineering, and the digital world (Himonides \& Purves, 2010), but it can also be observed in school teaching and learning practices.

The explosion of online music related resources has led to significant study and growth in the domain of music. Nowadays, people can create, produce, express, disseminate and promote music with the help of technology (Hugill, 2012). Music education is no exception, seeing more and more learning practices be actively incorporated into educational frameworks (Purves, 2012; Smart \& Green, 2017).

Studies have shown that technology use is flourishing in a growing set of educational contexts (Webster, 2012). As Himonides and Purves (2010) pointed out in a study based on a questionnaire addressed to music teachers, technology can undertake distinct roles in the class context, ranging from providing access to music for people with special needs or requirements, understanding music and/or the wider impact that music has on our lives and increasing teachers' abilities to assess the success of their students and their own teaching strategies.

While the relatively recent surge of such technologies is slowly but surely becoming a defining feature of the twenty-first century educational setting, the use of technology in teaching-specific activities remains underused, with such barriers as a lack of availability, technical and pedagogical competence, as well as institutional support (Fautley, 2013; Gall, 2013).

Even if technology has become a presence in music education, and has gradually started to shape the sphere of music learning, both in the classroom and beyond (Thorgersen \& Zandén, 2014), there is a world of difference between choosing to participate in online courses using technology and facing no choice but to exclusively learn and teach through the technology mediated 
venue, even if you, as a pre-service teacher, do not feel properly prepared to do so.

Teacher education, even more than other university programmes, implied rapid decisions, choices and adjustments in order to satisfy the demands of teacher education as well as the circumstances in which both higher education institutions and pre-university settings had to function (Flores \& Gago, 2020). Zhang et al. (2020) identified a number of challenges and constraints that were met by professionals and students in the context of the unexpected and 'forced' transition from face-to-face to remote teaching: lack of teachers' experience in delivering lessons through the online medium, the information gap (i.e., limited information and resources to all students), difficulties associated with poor online teaching infrastructure, the complex environment at home, etc.

A study conducted during the pandemic in a German university concluded that there had been an increase of students' stressful thoughts and feelings compared to 2019, when classes were held in a face-to-face setting (Rosset, Baumann \& Altenmüller, 2021). Another study was set to examine how the sudden schools and universities shut down affected the involvement of preservice music teachers. Most notable findings refer to lack of knowledge related to the planning and implementation of music instruction in the online modality (Thomas et al., 2021).

In this context, the present paper addresses the online teaching and learning experiences of second and third year music university students who are participating in the pre-service teacher education during the Covid-19 pandemic. We will explore in-depth the challenging experiences that preservice music teachers encountered during the Covid-19 school closure.

\section{Methodology}

As we already mentioned, this study's main objective is to investigate the challenging experiences that pre-service music teachers encountered during the Covid-19 school closure. In that respect, we will discuss the meaning of these experiences and its significance in the process of shaping their 
professional development. To meet this purpose, the study is designed as a phenomenological approach, which is a form of qualitative research that explains the meaning of a lived experience of a phenomenon for various individuals (Creswell, 2013). The phenomenology design was selected due to its focus on a comprehensive understanding of the participants' experiences on a particular phenomenon. The particular phenomenon under investigation is explored through 22 interviews (qualitative method) and has the aim of identifying commonalities between the participants' perceptions (Marshall \& Rossman, 2011). Accordingly, the phenomenological approach contributes to the understanding of real-life experiences of music students about experiences in the pre-service teacher education programme during the Covid-19 pandemic.

\subsection{Research participants}

In the current study, the participants were chosen based on a convenience sampling, i.e. they were conveniently located and willing to be involved in the study (Patton, 2002; Teddlie \& Yu, 2007). The selection of participants resorted to a convenience sample of individuals, in accordance with certain criteria, such as: enrollment in the teaching education programme in the $2^{\text {nd }}$ or $3^{\text {rd }}$ year at the university, as well as availability and eagerness to participate.

The participants of this study are pre-university music teachers $(n=22)$ meeting the above written criteria. Moreover, they are between ages of 20 and 41 years old. In the first phase of the sampling process, we contacted 35 pre-university music teachers in the $2^{\text {nd }}$ or $3^{\text {rd }}$ year at the university and provided all the necessary information regarding their future involvement in the research process via telephone and/or email. Only 22 of them agreed to take part in the study, as many explained that they were overloaded with activities and individual projects.

\subsection{Data Collection}

The data collection consisted of organizing semi-structured interviews which were conducted with each pre-service music teacher via ZOOM videotelephony software program in January-February 2021. The interviews 
lasted approximatively 40-50 minutes, and the students gave their consent to be audiotaped for a transcription and a better analysis of their responses. The questions of the interview focused on the experiences related to online teaching and learning during the school closure time without revealing any privacy information or looking into any delicate topics.

\subsection{Data analysis}

With the purpose of better analyzing the collected information, the data from the interviews were examined through qualitative content analysis (Bernard \& Ryan, 2010). The data was primarily descriptive and was transcribed verbatim and afterwards analysed. On the basis of the participants' responses at the interview questions, the analysis consisted firstly of coding the relevant broad categories in such a way the codes could be divided into different categories. In the end, we were able to group them into three main themes: (1) pre-service music teachers' positive experiences during online teaching and learning, (2) pre-service music teachers' negative experiences during online teaching and learning, and (3) technology.

\section{Findings}

In the present study, data shows that all pre-service music teachers overcame challenging moments while learning and teaching online. The content analysis revealed positive, as well as negative experiences during their online teaching and learning during the school closure. The experiences of the students are very diverse in the university context, ranging from participating in online classes from the position of student to delivering lessons and supporting preuniversity students in one-on-one online classes.

\subsection{Positive experiences during online teaching and learning}

In our study, reality shows that all music students enrolled in the teacher education programme had experienced challenges regarding their online teaching and learning, but at the same time they also encountered many positive aspects. 
As most of them pointed out, the digitally mediated environment had the advantage of providing flexible learning opportunities for the children they had worked with online. In the context of having one-on-one interactions with students, the pre-service teachers had more time to devote to each child and to support their learning process:

"Even if it may sound weird, I actually enjoyed this online teaching because it offered me the possibility to get to know the child better and work with her and help her more than I would have if there was an entire class. [...] The older generations, that did not have their practicum in the Covid period, had to work with an entire class and I know from a few older friends that it had been kind of tough, given the multiple activities they had besides the ones from the teacher education programme. So, yes, I really liked this period." $\left(3^{\text {rd }}\right.$ year pre-service music teacher).

Moreover, some students reported a sense of fulfillment during and after the time spent teaching and guiding the pupil:

"It gave me great joy to see that I can help a person to improve on so many levels. I worked with Maria for many weeks and I could see how the interactions were getting better and better each week. I was glad to answer her questions, help her with her homework and explain to her school related things she did not know. And I think this experience helped me become a better teacher. As one of our professors said in our first year of the teacher education programme, firstly you need to understand your pupil, to know his needs, his aspirations and then you can plan a learning process for him." ( $3^{\text {rd }}$ year pre-service music teacher).

According to music students' answers, they felt comfortable enough to reach out to their university teachers for guidance with the purpose of easing their practicum experiences:

"The teachers from the university were very supportive whenever I needed and asked for help. In the beginning, I had little interest in online teaching, because I was not used to deliver lessons in such a way, but with the help of some of my teachers, I gradually became accustomed to the new mode of teaching. It is indeed hard, but it may happen in the future, when I will be a teacher, so I should get 
the hang of it starting from now." ( $3^{\text {rd }}$ year pre-service music teacher).

Participating in online lessons can be a stress-provoking situation for all students, all the more so when it involves preparing to become a teacher. The music students acknowledged that the professors conducted the educational activity in a very professional manner. They tried to adapt each activity to the given context, even if it meant changed spatial and temporal relations.

"The teachers were really great! They adapted rather quickly to this whole new situation. [...] Okay, not immediately, but they were very eager to make us feel comfortable and I could see they tried different strategies to plan and deliver the lessons to us." $\left(2^{\text {nd }}\right.$ year pre-service music teacher).

As a consequence of the exclusively virtually mediated context, the professors used a variety of technology resources to help music students engage in their activities for planning, instruction, and assessment. In this way, students became more knowledgeable in terms of technological devices which can be adapted for educational purposes, as these experiences helped them identify the benefits of using digital media when conducting educational activities.

4.2. Negative experiences during online teaching and learning

Pre-service teachers have been exposed to different technologies in their educational experiences, but this exposure may not have developed the necessary competences needed to adequately implement pedagogical content for music classes with pupils. As the current context has forced teacher education programmes to adapt to an exclusively online format, the situation led to some areas of dissatisfaction.

Most notably, students reported being overwhelmed with other work, which most of the times led to a lack of engagement in the preparation of becoming a teacher.

"I had so many projects this past months that I was not able to always participate at lessons or activities. Teachers from all subjects 
should talk to each other and see how many things we have to do and somehow organize the projects in order for us to be able to have at least a relaxing weekend once a month. It is seriously tiring. [...] And I am one of the few students that does not have a personal musical project at the moment." (2 ${ }^{\text {nd }}$ year pre-service music teacher). "These past months were so nerve-racking because I had so many things to do. I confess that I was not able to dedicate enough time to the teacher programme. How could I have when I had so many things to do this semester?" ( $3^{\text {rd }}$ year pre-service music teacher).

Other students felt a sense of loss because they were not able to have faceto-face interactions with their colleagues and teachers:

"I really did not like this period. I always had the need to look the other person in the eye, to notice his/her gestures, etc. And I could not do this online. We should have also prepared a lesson in the class with the other colleagues, in which we could have organized participatory hands-on activities. We could have, but we didn't, unfortunately." ( $2^{\text {nd }}$ year pre-service music teacher).

In consonance with the above-mentioned experiences, there were many instances where the students struggled with a lack of motivation for participating in the online classes, the reasons being different from person to person:

"I dread this period and we still have our lessons online right now. Sometimes I cannot concentrate, the internet is often very slow, so I have to go out at a friend to get a better connection. I hope that the next academic year will be face-to-face." ( $2^{\text {nd }}$ year pre-service music teacher).

"When I think of the fact that most of my university experiences have been organized online... it scares me. I wished we studied in class. It is not fair and I do not like it a bit." (2 $2^{\text {nd }}$ year pre-service music teacher).

\subsection{Technology}

A common trait of this period seemed to be the weak Internet connection that many students dealt with from time to time. The pre-service teachers 
had their homes in urban, suburban and rural settings all over Romania, so some students lacked Internet access and speed. The lessons were also asynchronous, but mostly synchronous. Therefore, not all the students had the same chance of participating at the courses and seminars:

"I struggled with Internet instability the whole semester, and I live in an urban area. I have colleagues who live in rural areas and they had major problems especially when there were storms." ( $2^{\text {nd }}$ year pre-service music teacher).

\section{Discussion and conclusions}

Covid-19 resulted in tremendous change and disruption in every aspect of our lives. Education is no exception. In order to support the educational systems, international organisations and national governments have tried to mitigate the impact of school closure, with an emphasis on vulnerable communities. Based on prior knowledge on online teaching, learning and evaluating, the professionals tried to develop careful instructional design and planning (Hodges et al., 2020).

In the present study we seek to comprehend the pre-service teachers' experiences with online teaching and learning during Covid-19 pandemic at a music university. Three topics were explored: positive experiences during online teaching and learning, negative experiences during online teaching and learning, and technology related challenges.

The data pointed towards a neither overtly positive or negative teaching and learning experience, even if the students had to navigate an avalanche of offline learning technology requirements both as students and teachers in a limited amount of time. Thus, they had no other choice but to plunge deeply into the various approaches employed to teach music remotely.

A common concern expressed by the music students was related to the work overload, the lack of motivation and disengagement which were seen as consequences of the forced adaptation to an exclusively online format for educational activities. Also, Internet access and stability posed some serious problems to students. 
Nevertheless, the pre-service music teachers also pointed to some benefits associated with this mode of teaching and learning, mainly related to being able to provide flexible learning opportunities for the children they had worked with online, feeling a sense of fulfillment and the support received from their university teachers throughout the whole academic year.

Based on the data collected in this study, teacher training programmes should consider the move to virtual teaching and learning as an opportunity for change and to go beyond the emergency online practices and develop quality online educational activities. The findings emphasized the need for an allembracing view of the pedagogy of online education that incorporates technology to assist the teaching, learning and evaluation processes.

\section{NOTES}

1. The contribution of the authors to this paper is equal.

\section{References}

- Bernard, H. R., \& Ryan, G. W. (2010). Analyzing qualitative data: Systematic approaches. Sage.

- Botnariuc, P., Cucoş, C., Glava, C., Iancu, D. E., Istrate, O., Labăr, A.V., Pânişoară, I. O., Ştefănescu, D., \& Velea, S. (2020). Şcoala online. Elemente pentru inovarea educa iei. Raport de cercetare evaluativă. Editura Universită ii din Bucureşti.

- Brown, S. M., Doom, J. R., Lechuga-Peña, S., Watamura, S. E., \& Koppels, T. (2020). Stress and parenting during the global COVID-19 pandemic. Child Abuse \& Neglect, 106, 1-14. https://doi.org/10.1016/j.chiabu.2020.104699

- CEDEFOP. (2020). Romania: responses to the Covid-19 outbreak. https://www.cedefop.europa.eu/en/news-and-press/news/romania-responsescovid-19-outbreak

- Creswell, J. W. (2013). Qualitative Inquiry \& Research Design: Choosing Among the Five Approaches. SAGE Publications.

- Dalu, A.-M. (coord.), Apostu, O., Blendea, P., Fartuşnic, C., Horga, I., Iftode, O., Lazăr, M., Miulescu, M., Plăeşu, A., Scoda, A., ăranu, A. M., \& Voinea, L. (2021). Invă area la distan ă. Studiu cu privire la activită ile educa ionale desfăşurate în România, în perioada suspendării cursurilor şcolare fa ă-în-fa ă. Editura Trei. 
- Donitsa-Schmidt, S., \& Ramot, R. (2020). Opportunities and challenges: teacher education in Israel in the Covid-19 pandemic. Journal of Education for Teaching, 46(4), 586-595. https://doi.org/10.1080/02607476.2020.1799708

- Fautley, M. (2013). The potential of audio and video for formative assessment purposes in music education in the lower secondary school in England: issues arising from a small-scale study of trainee music teachers. Journal of Music, Technology \& Education, 6(1), 29-42. https://doi.org/10.1386/jmte.6.1.29_1

- Flores, M. A., \& Gago, M. (2020). Teacher Education in Times of COVID-19 Pandemic in Portugal: National, Institutional and Pedagogical Responses. Journal of Education for Teaching, 46(4), 507-516.

https://doi.org/10.1080/02607476.2020.1799709

- Gall, M. (2013). Trainee teachers' perceptions: factors that constrain the use of music technology in teaching placements. Journal of Music, Technology \& Education, 6(1), 5-27. https://doi.org/10.1386/jmte.6.1.5_1

- Himonides, E., \& Purves, R. (2010). The role of technology. In S. Hallam \& A. Creech (Eds.), Music Education in the 21st Century in the United Kingdom: Achievements, Analysis and Aspirations (pp. 123-140). London Institute of Education.

- Hodges, C., Moore, S., Lockee, B., Trust, T., \& Bond, A. (2020, March 27). The difference between emergency remote teaching and online learning. Educause review. https://er.educause.edu/articles/2020/3/the-difference-betweenemergency-remote-teaching-and-online-learning

- Hugill, A. (2012). The Digital Musician (2nd ed.). Routledge.

- Ling, L. M. (2017). Australian teacher education: inside-out, outside-in, backwards and forwards?. European Journal of Teacher Education, 40(5), 561-571. https://doi.org/10.1080/02619768.2017.1385599

- Marshall, C., \& Rossman, G. B. (2011). Designing qualitative research. Sage Publications.

- Patton, M. Q. (2002). Qualitative research and evaluation methods. Sage Publications.

- Pozo, J.-I., Pérez Echeverría, M.-P., Cabellos, B., \& Sánchez, D. L. (2021). Teaching and Learning in Times of COVID-19: Uses of Digital Technologies During School Lockdowns. Frontiers in Psychology, 12, 1-13. https://doi.org/10.3389/fpsyg.2021.656776

- Purves, R. (2012). Technology and the educator. In G. E. McPherson \& G. F. Welch (Eds.), The Oxford Handbook of Music Education (2nd ed., pp. 457-475). Oxford: Oxford University Press.

- Rosset, M., Baumann, E., \& Altenmüller, E. (2021). Studying Music During the Coronavirus Pandemic: Conditions of Studying and Health-Related Challenges. Frontiers in Psychology, 12, 1-11. https://doi.org/10.3389/fpsyg.2021.651393 
- Smart, T., \& Green, L. (2017). Informal learning and musical performance. In J. Rink, H. Gaunt \& A. Williamon (Eds.), Musicians in the Making: Pathways to Creative Performance (pp. 108-125). Oxford University Press.

- Teddlie, C., \& Yu, F. (2007). Mixed Methods Sampling: A Typology with Examples. Journal of Mixed Methods Research, 1(1), 77-100.

https://doi.org/10.1177/1558689806292430

- Thomas, M. A., Norgaard, M., Stambaugh, L. A., Atkins, R. L., Kumar, A. B., \& Farley, A. L. P. (2021). Online Involvement for Georgia Student Teachers During Covid-19. Frontiers in Psychology, 12, 1-11.

https://doi.org/10.3389/fpsyg.2021.648028

- Thorgersen, K., \& Zandén, O. (2014). The internet as teacher. Journal of Music, Technology \& Education, 7(2), 233-244. https://doi.org/10.1386/jmte.7.2.233_1

- UNESCO. (2021). One year into COVID: Prioritizing education recovery to avoid a generational catastrophe. Report of UNESCO online conference. https://unesdoc.unesco.org/ark:/48223/pf0000376984

- United Nations Educational Scientific and Cultural Organization. (2020). COVID19 impact on education.

- Webster, P. R. (2012). Key research in music technology and music teaching and learning. Journal of Music, Technology \& Education, 4(2-3), 115-130. https://doi.org/10.1386/jmte.4.2-3.115_1

- Zhang, W., Wang, Y., Yang, L., \& Wang, C. H. (2020). Suspending Classes without Stopping Learning: China's Education Emergency Management Policy in the COVID-10 Outbreak. Journal of Risk and Financial Management, 13(58), 1-6. https://doi.org/10.3390/jrfm13030055

The online version of this article can be found at: http://revped.ise.ro/category/2021-en/

\section{$(C c)) B Y-N C-S A$}

This work is licensed under the Creative Commons Attribution-NonCommercial-ShareAlike 4.0 International License.

To view a copy of this license, visit http://creativecommons.org/licenses/by-nc-sa/4.0/ or send a letter to Creative Commons, PO Box 1866, Mountain View, CA 94042, USA.
Versiunea online a acestui articol poate fi găsită la: http://revped.ise.ro/category/2021-ro/

\section{(cc)}

Această lucrare este licen iată sub Creative Commons Attribution-NonCommercial-ShareAlike 4.0 International License.

Pentru a vedea o copie a acestei licen e, vizita $i$ http://creativecommons.org/licenses/by-nc-sa/4.0/ sau trimite i o scrisoare către Creative Commons, PO Box 1866, Mountain View, CA 94042, SUA. 